\title{
Article \\ Article \\ A Structural Equation Model for Measuring the Impact of Human Resource Management Practices and Organizational Loyalty on Employee Retention: An Indian Perspective
}

\author{
Dr. Deepa Naidu ${ }^{1,}$ * , Prof. Devi Rajesh ${ }^{2+}$ \\ 1.Assistant Professor, KLU-Business School, K L University,Green Fileds, Vaddeswaram, Andhra Pradesh \\ atdeepa@kluniversity.in \\ 2. Assistant Professor, Department of Management Studies, Indira Institute of Engineering and Technology, \\ Chennai, Tamil Nadu. \\ divishree87@gmail.com \\ * Correspondence: atdeepa@kluniversity.in; Tel.: +91 7871573719
}

\begin{abstract}
The role of human resource management practices and organizational loyalty dealing with employee retention has been widely explored and examined in the existing literature. The majority of human resource management researchers have focused on the role of policies and practices in different sectors related to employee retention. However, less attention has been given to identifying the practices and procedures common across all industries and sectors. The present study attempts to determine and examine the most important constructs like HR practices and organizational loyalty of employee retention management and proposes a comprehensive structural equation model to measure the impact of these constructs on employee retention. After an extensive review of the literature, organizational loyalty, and human resources management practices like recruitment and selection, compensation and benefit, training and development, supervision and evaluation have been identified as four essential practices dealing with employee retention and are common across all industries. These practices constitute the component factors of an employee retention management predicting employee's turnover intentions. The survey method was adopted, and the original data obtained through the self-administered questionnaire. The valid one hundred and eighty-nine (189) respondents analyzed by using Lisrel 8.7, Structural equation model (SEM) analysis results shows that human resource management practices and organizational loyalty have strong positive impact on employee retention. This study tends to assist human resource managers and decision makers in selecting the appropriate motivating factors to retain and satisfy their employees
\end{abstract}

Keywords: Organizational loyalty, human resource management practices, structural equation modeling, employee turnover and employee retention

\section{Introduction}

There is a significant problem of turnover in any of the organization. It is a misperception that all turnovers are awful, and that must evade. But actually if an organization does not have a balanced level of turnover, it will result in the monotonous system, and that organization will not have access to new ideas, change dynamism and creativity. Turnover influences profitability and customer satisfaction (Koys, 2001). Our concern is that the required 
44 turnover must exist, but the unwanted voluntary turnover should be reduced or avoided. In 45 today's competitive environment employees leave their organization for various reasons. As 46 the knowledge of employees have become highly critical in gaining competitive advantage in 47 today's business climate (Hall, 1993). The organizations are trying to retain the best 48 employees. The Importance of human resource management practices and organizational 49 loyalty and their retention is recognized. Initially, because resources are scarce and secondly because the competition by businesses to have the best and most talented employees for their 51 organization (Chambers et al., 1998) and finally because Turnover also destroys the customer confidence in the company (Koys, 2001). Customers don't want to teach about their needs to the new employees. So it is better to retain employees that can keep customers.

54 In the competitive environment, the retention of skilled employees is terrible. Top management \& HR department put in an extensive time, financial resources and effort to find out the way to retain their employees and gain competitive advantage (Bartlett \& Ghoshal, 2013). Training efforts are also use to maintain employees (Chen, 2014).

The research in this area is segmented, and either one or few variables have been understudy e.g. one researcher worked on the impact of human resource management training on retention, and the other investigator worked on how promotion, awards, and supervision significance's employee retention. Work has done on the organizational citizenship behavior; that leads to retention. Career opportunities, work-life policies, job characteristics, etc. however, no work of literature has tried to integrate and consolidate the various factors that have been studied empirically in a single body of work. This paper incorporates all this segmented work into an integrated conceptual model which will help organizations to take care of all factors that influence employee retention instead of one or two of them. Next in this paper, the literature review of all variables mentioned above is discussed in detail followed by the conceptual model. Finally, you will see the conclusion section in which suggestions are given for organizations to retain the employee. Impending research directions also proposed in the paper.

\section{2. Research Gap Addressed}


72 This study aimed to rectify the gap in the existing literature and provide valuable insights that 73 may clarify the differences in HRM practices and the importance of organizational loyalty 74 that affect employee retention and also check the mediation role of organizational loyalty 75 between $\mathrm{hr}$ practices and employee retention. Therefore the study captures all essential 76 information and more amenable to estimation and discussion. As a result, the retention approach considered the most efficient research design to effectively explore the broad objectives of the study

\section{Literature Review:}

Taylor (2002) introduces two perspectives on retention. The first one states that reducing the employee turnover rate is desirable for all organizations and that the fact it should be the aim of initiatives in the employee retention. It also suggests that improving retention/turnover rates in general is or should be a central objective of human resource management policy. According to this perspective, high levels of turnover are often seen as evidence of failing in human resource functions. The author also introduces another perspective on the matter: after a "new world of work" has emerged, the retention rates have raised because of the flexibility of labor market. It said that this is desirable, and the organizations should focus their efforts on the retention of the most outstanding performers, those few people in each section who can make a difference in the business.

After this, the author states his perspective, that even though he thinks that both of the perspectives are right in their way, in his opinion the employee turnover is always damaging the organization, and none of the employees should be as no important. According to him, most of the employees at different levels of organizations are so called average workers, but they, in fact, ensure that the show goes on and take care of the fundamental objectives of the organization leaving room for the excellent performers to shine. This researcher reminds that there is a cost in every "departure" of even the below average performers of Taylor's (2002), The Three Rs of Employee Retention. Hausknecht et al., 2009, listed 12 most important retention factors that have published in the journals over the last 60 years which helped in explaining employee retention. 
100 Employee retention consists of 3 R's which helps in retaining valuable employees. To keep

101 such employees and maintain high in satisfaction, you have to implement each of the three Rs

102 of employee retention. The three R's are; Respect, Recognition, and Rewards

103 Respect is value, particular consideration or special regard given to employees. The first R,

104 respect is the foundation of maintaining your employees. Recognition and rewards will have

105 modest effect if you don't recognize your employees.

106 Recognition is referred as "special observe or attention" and "the act of perceiving clearly."

107 various problems with retention and confidence occur because management is not paying

108 attention to employee's needs and reactions.

109 Rewards are the extra perks that a company offers beyond the basics of respect and

110 recognition that makes it worth employee's while to work hard and to take care of their job.

\section{$111 \quad 3.1$ Human Resource Management Factors Influencing Employee Retention}

112 There are rising facts that HRM can play a significant role in retaining skilled professional at 113 any organization. Researchers of progressive HRM practices in training and development, 114 supervision, and evaluation, recruitment and selection, compensation and benefits have 115 revealed that these can lead to reducing employee turnover and absenteeism (Arthur1994;

116 Huselid M,A. 1995 and Delaney and Huselid 1996). According to Fitz-enz (1990), 117 managing retention of employees is influenced by many factors, which should lead 118 congruently; recruitment and selection, compensation and benefits, training and development 119 and employee support programs. Similarly, Compensation affects the recruitment and 120 retention of employees and therefore playing an important role in managing people (Rynes 121 and Barber 1990; Williams and Dreher 1992 Highhouse.et al., 1999; Parker and Wright 122 2001). In 2003, there was a study conducted by Mercer; he stated that employees remain 123 with the present organization if they rewarded. Usually, workers are paid when they 124 performed better in their work, and they perform better due to their loyalty towards the 125 organization. Employees tend to remain with the current team when they feel their efforts and 126 performance, abilities contributed are renowned and valued by the organization (Davies, $\mathrm{R}$ 127 2001). There are also studies that have highlighted the rewarding practices of workers will 128 help the organization in retaining employees (Watson Wyatt1999, Mercer 2003; Tower 
129 Perrin 2003). In today's organization finding to get the more skilled employees, the more

130 likely they are to remain. Indeed, when the training ends, the turnover tends to begin (Jamrog

131 2002; Wien-Tuers and Hill 2002).

\section{$132 \quad 3.2$ Organizational Loyalty Influences Employee Retention}

133 Loyalty, as a general term signifies a person's devotion or sentiment of attachment to the 134 organization. Workers who felt that the organization failed to treat them challenging and 135 interesting work, opportunities to develop their skills and autonomy were more likely

136 negatively and lacked loyalty towards the organization and greater level of intention to quit 137 the job (Phillips 1997). The loyalty of employee can be determined through direct 138 questioning no one can assume whether employees today work efficiently (Angle, 1983).

139 (Streers, 1977) believes that organizational loyalty is the strength of the competition (link) 140 between the individual with his organization and his association with it. (Allen \& Meyer, 141 1990) showed that loyalty is a psychological condition reflects the relationship of the person 142 in the organization in which it operates by Porter, et al., 1979 and also identified the loyalty 143 as the strength of correlation of the individual with its organization, and that the person who 144 shows a high level of organizational loyalty in the organization. In which it operates it has a 145 strong belief to accept the goals and values of the organization, ready to make every possible 146 effort to serve the organization, and has a strong desire to continue working in such 147 organization

\section{The following research objectives were developed to guide the study}

150 1. Is there a relationship between human resource management practices and employee 151 retention?

152 2. Is there a relationship between organizational loyalty and employee retention?

153 3. Does organizational loyalty acts as a mediator between human resource management 154 practices and employee retention?

155 1. Hypotheses of the study:

$156 \mathrm{H} 1$ : There is a relationship between human resource management practices and 157 organizational loyalty on employee retention 
$158 \mathrm{H} 2$ : Organizational loyalty mediates the relation between human resources management

159 practices and employee retention

160

161 2. Research Model/Theoretical framework of the study

162 This study assessed organizational loyalty and human resource practices and how it helps

163 retaining employees in health care sectors.

164 As shown in figure 1, organizational loyalty and human resource management practices are

165 the observed variables under the independent construct.

166 Based on the above hypotheses, the theoretical framework has been framed in figure 1 and

167 figure2.

168 The independent variables in this study are human resource management practices and

169 organizational loyalty, and the dependent variable is employee retention.

170

171 Figure 1: shows the independent variables that influence the dependent variable.

172 Figure 2: shows the mediation effect of loyalty between HRM practices and employee 173 retention.

174

175

176

177

178

179

180

181

182

183

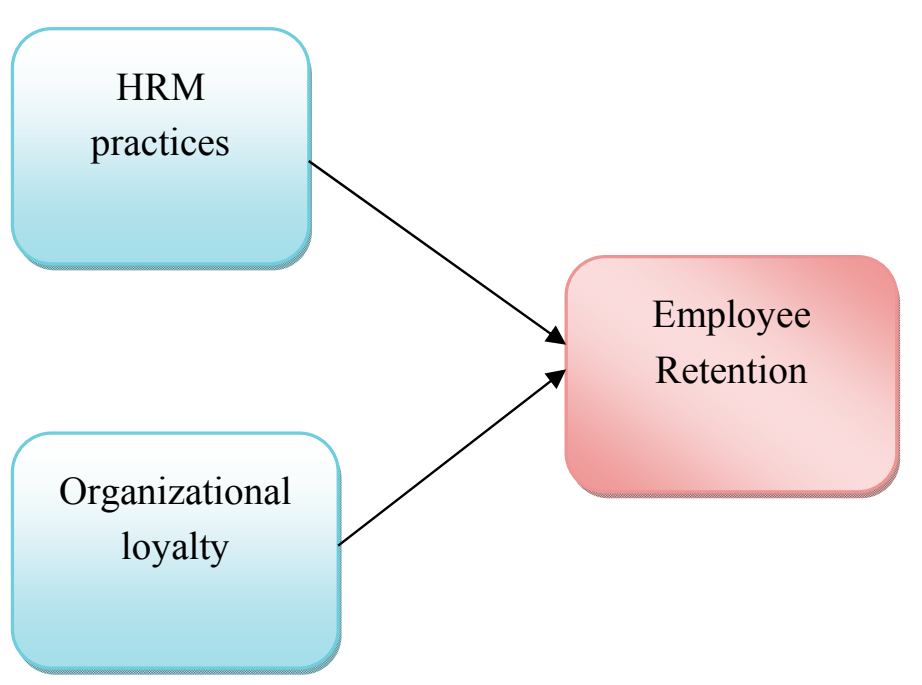


187

188

189

190

191

192

193

194

195

196

197

198

199

200

201

202

203

204

205

206

207

208

209

210

211

212

213

214

Figure 2: Mediation Model of the study

\section{HRM Practices}

Recruitment \& Selection

Training \& Development

Compensation \& Benefits

Supervision \& Evaluation
Organizational

Loyalty
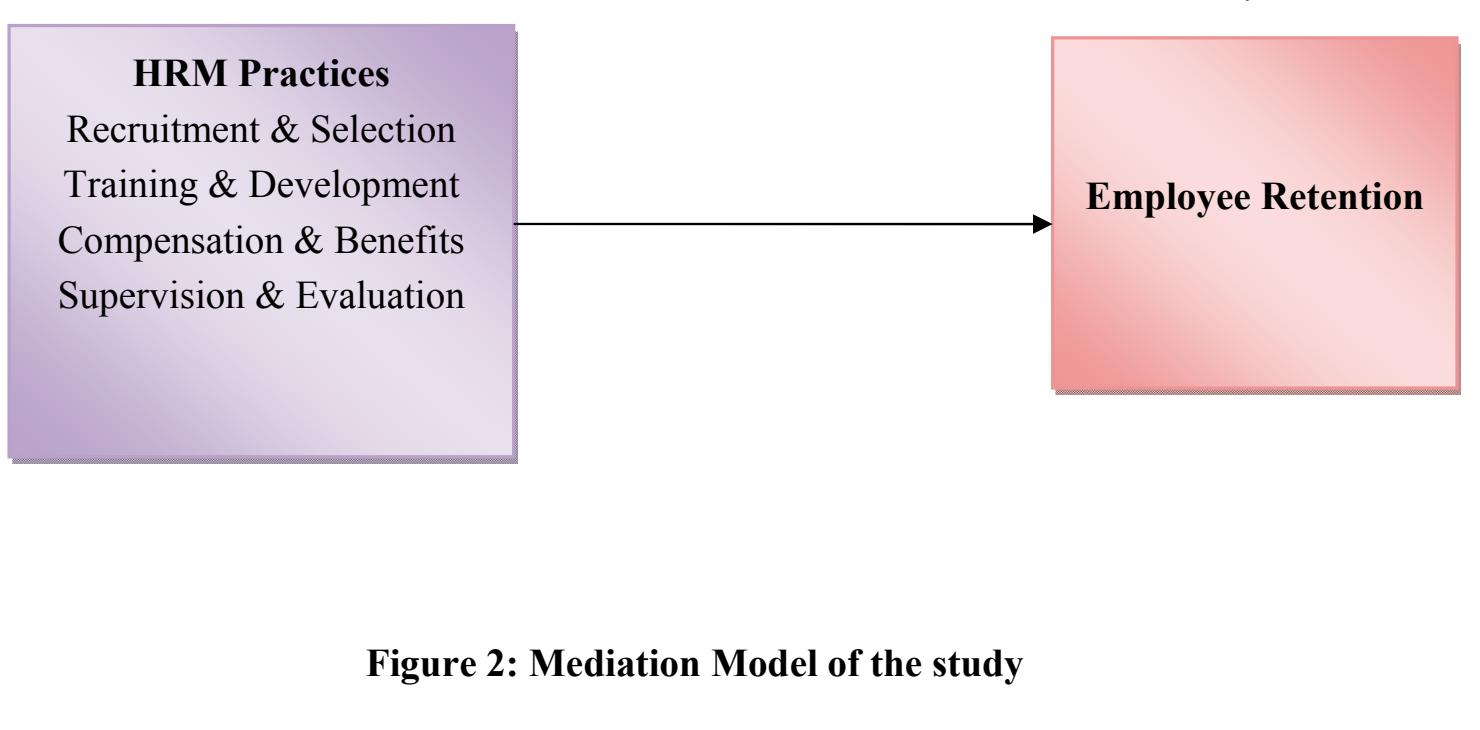

\section{Methodology}

The research method involved a survey method. The questionnaires were developed based on literature studies. Convenience and snowball sampling method were used to conduct the study and carried out in each organization, with about 70-100 employees. The questionnaire distributed to 350 workers, with 189 returned. This 57 percent responded rate was deemed acceptable (Comrey and Lee 1992). They were given two weeks time to finish the survey.

We got weak responses from some organization.

\section{Data Collection and Sample population}

SPSS Version 20 (Statistical package for social sciences) and Lisrel 8.7 were used to analyze the quantitative data. All items were coded from 1-5 using Likert 5 point scale (Strongly Agree to Strongly Disagree). The statistical analysis includes reliability, EFA (exploratory factor analysis) and Structural equation modeling (CFA) using Lisrel 8.7 
215 The population sample used in this study consisted of health care professionals from Tamil

216 Nadu and Andhra Pradesh. The participating organization was from hospital sectors, 217 manufacturing sectors and also included industry sectors.

\section{5. Measurement}

219 Multiple items adopted and modified from various studies have been used to measure the 220 employee retention and the constructs of this study. Human resource management practices 221 and organizational loyalty, employee retention have been measured with 14 and 21 items 222 each by following Nelson McCann(2010), Fischer (2011) and Spreitzer (1995) where all 223 the elements have acceptable and reliability above the acceptance level. i.e., human resource 224 management practices (0.88), organizational loyalty (0.89) and employee retention (0.72).

\section{Data Analysis}

226 We present in the following the results of reliability analysis (spss), linear regression (spss), 227 hierarchical linear modeling (spss) and confirmatory factor analysis model (Lisrel-8.7) and 228 additional analyses.

\section{$229 \quad 6.1$ Reliability of the Instruments}

230 An alpha of 0.70 or above is considered to be reliable as suggested by many researchers 231 (Nunnally 1978 and Davis 1996). It is seen from the below table that all constructs in the 232 study have reliability above the suggested alpha value.

\begin{tabular}{|c|c|}
\hline Constructs & $\begin{array}{c}\text { Cronbach's alpha } \\
\text { (obtained for the study) }\end{array}$ \\
\hline $\begin{array}{c}\text { People Management Practices } \\
\text { (4 Constructs-21 items) }\end{array}$ & 0.89 \\
\hline Organizational Loyalty \\
(21 items)
\end{tabular}


235 Regression analysis of human resource management practices on employee retention

\begin{tabular}{|l|r|r|r|c|}
\hline Model & $\mathrm{R}$ & R Square & $\begin{array}{c}\text { Adjusted R } \\
\text { Square }\end{array}$ & $\begin{array}{c}\text { Std. Error of the } \\
\text { Estimate }\end{array}$ \\
\hline 1 & $.795^{\mathrm{a}}$ & .632 & .630 & 5.62917 \\
\hline
\end{tabular}

a. Predictors: (Constant), HRM

236

Coefficients $^{\mathrm{a}}$

\begin{tabular}{|c|c|c|c|c|c|c|}
\hline \multirow{2}{*}{\multicolumn{2}{|c|}{ Model }} & \multicolumn{2}{|c|}{ Unstandardized Coefficients } & \multirow{2}{*}{$\begin{array}{c}\text { Standardized } \\
\text { Coefficients } \\
\text { Beta }\end{array}$} & \multirow[t]{2}{*}{$\mathrm{t}$} & \multirow[t]{2}{*}{ Sig. } \\
\hline & & B & Std. Error & & & \\
\hline \multirow{2}{*}{1} & (Constant) & 12.436 & 1.789 & & 6.951 & .000 \\
\hline & HRM & .513 & .029 & .795 & 17.907 & .000 \\
\hline
\end{tabular}

a. Dependent Variable: ER

237

Regression analysis of organizational loyalty on employee retention

\begin{tabular}{|l|r|r|r|c|}
\hline Model & \multicolumn{1}{|c|}{ Model Summary } \\
\hline 1 & $.714^{\mathrm{a}}$ & .510 & $\begin{array}{c}\text { Adjusted R } \\
\text { Square }\end{array}$ & $\begin{array}{c}\text { Std. Error of the } \\
\text { Estimate }\end{array}$ \\
\hline
\end{tabular}

a. Predictors: (Constant), OL

\section{Coefficients $^{a}$}

\begin{tabular}{|c|c|c|c|c|c|c|}
\hline \multirow{2}{*}{\multicolumn{2}{|c|}{ Model }} & \multicolumn{2}{|c|}{ Unstandardized Coefficients } & \multirow{2}{*}{$\begin{array}{c}\text { Standardized } \\
\text { Coefficients } \\
\text { Beta }\end{array}$} & \multirow[t]{2}{*}{$\mathrm{t}$} & \multirow[t]{2}{*}{ Sig. } \\
\hline & & B & Std. Error & & & \\
\hline \multirow{2}{*}{1} & (Constant) & 14.485 & 2.142 & & 6.762 & .000 \\
\hline & $\mathrm{OL}$ & .450 & .032 & .714 & 13.945 & .000 \\
\hline
\end{tabular}

a. Dependent Variable: ER

240

241

242

243

244

245

246

Hypothesis1: There is a positive significant impact of HRM practices and organizational loyalty on employee retention.

\subsection{Hierarchical Regression Analysis for Mediation analysis}

Hierarchical Regression analysis of HRM practices, organizational loyalty on employee retention

\begin{tabular}{|l|r|r|r|c|}
\hline Model & $\mathrm{R}$ & $\mathrm{R}$ Square & $\begin{array}{c}\text { Adjusted } \mathrm{R} \\
\text { Square }\end{array}$ & $\begin{array}{c}\text { Std. Error of the } \\
\text { Estimate }\end{array}$ \\
\hline 1 & $.795^{\mathrm{a}}$ & .632 & .630 & 5.62917 \\
\hline
\end{tabular}




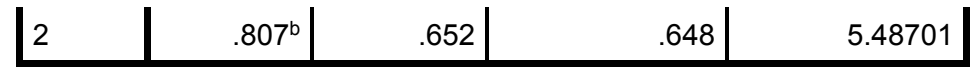

a. Predictors: (Constant), PMP

b. Predictors: (Constant), PMP, OL

\begin{tabular}{|c|c|c|c|c|c|c|}
\hline \multicolumn{7}{|c|}{ Coefficients $^{a}$} \\
\hline \multirow{2}{*}{\multicolumn{2}{|c|}{ Model }} & \multicolumn{2}{|c|}{ Unstandardized Coefficients } & \multirow{2}{*}{$\begin{array}{c}\text { Standardized } \\
\text { Coefficients } \\
\text { Beta }\end{array}$} & \multirow[t]{2}{*}{$\mathrm{t}$} & \multirow[t]{2}{*}{ Sig. } \\
\hline & & B & Std. Error & & & \\
\hline \multirow{3}{*}{1} & (Constant) & 12.436 & 1.789 & & 6.951 & .000 \\
\hline & HRM & .513 & .029 & .795 & 17.907 & .000 \\
\hline & (Constant) & 10.152 & 1.877 & & 5.408 & .000 \\
\hline \multirow[t]{2}{*}{2} & HRM & .396 & .045 & .613 & 8.713 & .420 \\
\hline & $\mathrm{OL}$ & .146 & .044 & .231 & 3.289 & .001 \\
\hline
\end{tabular}

a. Dependent Variable: ER

248

249 Hypothesis 2: organizational loyalty mediates the relation between HRM Practices and 250 employee retention.

251 The first hypothesis of the study was that HRM practices and organizational loyalty influence

252 the employee retention. According to the table of regression, Analysis p-values show the 253 significant relationship between the HRM practices and organizational loyalty and employee 254 retention. Hence, hypothesis stood true. The R-square values of $63 \%$ and $50 \%$ are the 255 variance of employee retention that is explained by the constructs.

256 The second hypothesis stated that organizational loyalty positively influences the HRM 257 practices and employee retention.

258 According to the table of regression Analysis p-values shows the significant relationship 259 between the HRM practices and employee retention in the enter method when we added the 260 second construct that is mediating variable (organizational loyalty) the significance value of 261 HRM practices that becomes non-significant, which proving the hypothesis correct. The 262 impact of the organizational loyalty as per Beta value, i.e., 0.146 on Employee Retention is 263 found almost $66 \%$.

\section{$264 \quad$ 6.3.1 Mediation Analysis}

265 Mediation analysis has been used to see the impact of independent variable (human resource 266 management practices) on dependent variable (employee retention) in the presence of 
11 of 16

267 mediating variable (organizational loyalty). The method suggested by Baron and Kenny 268 (1986) has been used to find out the effect of the mediating variable. These results show that 269 organizational loyalty fully mediated the relationship between HRM practices and employee 270 retention. All steps are used as described by Baron and Kenny (1986) and Judd and Kenny 271 (1981).

\section{7. Structural Equation Modeling}

273 SEM-Confirmatory factor analysis Human resource management practices, organizational 274 loyalty, and Employee retention

275 From the below figures it can be seen that all the items that have fallen under respective 276 constructs and also having the value of above .4 and the table shows the GFI, NFI, NNFI, 277 RMSEA and all the values are met acceptable fit indices as suggested by Joreskog and 278 Sorbom (1984).Confirmatory Factor Analysis (CFA) is a type of analysis in contrast with 279 Exploratory Factor Analysis (EFA). This study conducts CFA on the two independent 280 variables and dependent variable (figure 3) and also the CFA has done for all the constructs 281 in the study (human resource management practices and organizational loyalty) in figure 4. 282

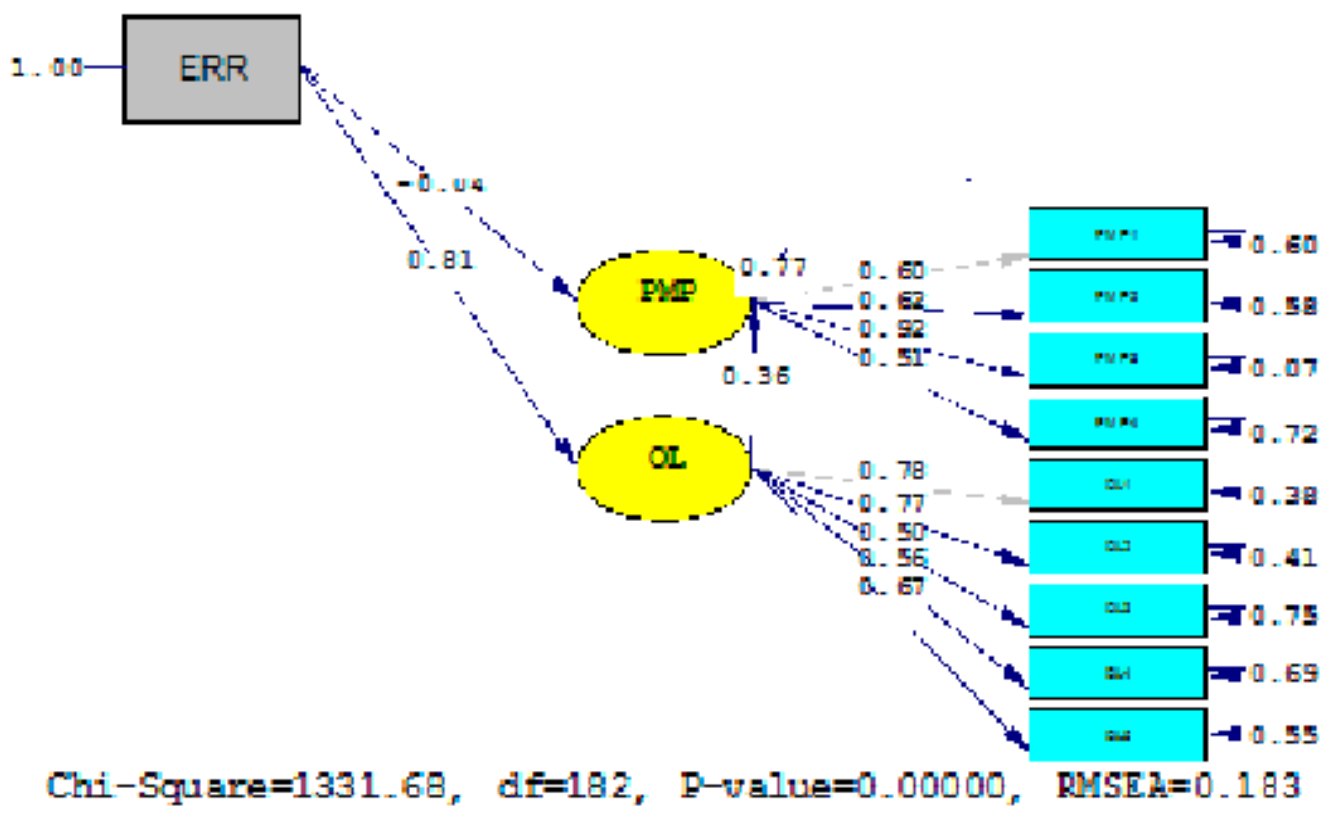


12 of 16

284 Figure 3: shows the CFA of the independent constructs and related with employee retention 285 in the study

\section{Chi-square=154 . 55, df=26, P-Value=0.00000, RMSER =0.038}

286

287

288

289

290

291

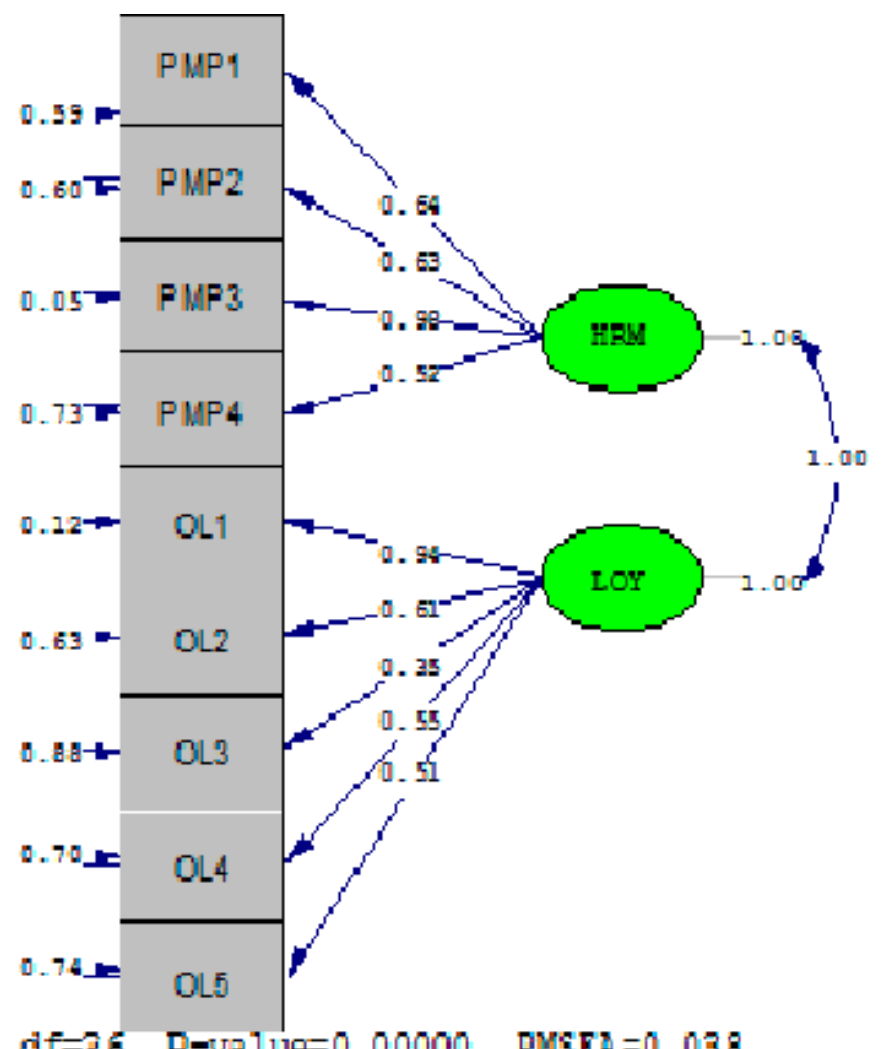

Figure 4: shows the CFA of the independent constructs in the study

Overall Fit Certification After the literature review and the factor analysis on sampled data, this study constructs the overall model and, as suggested by Hair, Anderson, Tatham, , and Black (1998) classifies the measurement of the overall model fit into three categories, i.e. measures of absolute fit, increment fit and parsimonious fit.

\begin{tabular}{|c|c|c|c|c|c|c|c|}
\hline Constructs & $\begin{array}{l}\text { Chi } \\
\text { Square } \\
\text { value }\end{array}$ & NFI & CFI/TLI & GFI & NNFI & AGFI & RMSEA \\
\hline HRM & 74.54 & 0.97 & 0.92 & 0.91 & 0.91 & 0.86 & 0.053 \\
\hline OL & 69.65 & 0.90 & 0.95 & 0.94 & 0.83 & 0.89 & 0.078 \\
\hline ER & 62.71 & 0.96 & 0.90 & 0.93 & 0.99 & 0.80 & 0.035 \\
\hline
\end{tabular}

293 Table 2 : shows the results of the overall fit test 
13 of 16

295 The primary objective of this study is to identify the impact of human resource management

296 practices and organizational loyalty on employee retention. Two hypotheses have framed in

297 this study and they both are accepted. Results of the survey revealed that human resources

298 management practices and organizational loyalty have a positive significant impact on

299 employee retention. Secondly, organizational loyalty plays an important mediating role

300 between human resource practices and retaining the employees in any organization.

301 Organization should take responsible for recruiting people, practices, training, compensation

302 and supervision to their employee so that they can improve their behavior and must loyalty

303 with their organization. Both the hypotheses accepted in the study that there is a significant

304 positive influence of human resource management practices and organizational loyalty on

305 employee retention, and organizational loyalty plays a mediation role in human resource

306 management and employee retention.

307 Recommendations for future research

308 It is found that organizational loyalty has a significant role in mediating human resource

309 management practices and retaining of employees, but there needs to be an improvement in

310 the area of Training \& Development, Compensation, and benefit. To avoid such gaps,

311 Organization must have to take care of Employees Training \& Development, Compensation

312 and benefits which create loyalty among employees. Apparently, it has to be on a normal

313 interval which not only progresses \& enhance their skills but also increases the productivity

314 of any organization. It is also important to retain resources while offering other benefits like

315 wellbeing, encouragement, skill development, participative approach, two-way interactions, 316 etc.

\section{9. References}

318 1. Allen and Meyer (1990), "The Measurement and Antecedents of Affective, 319 Continuance and Normative Commitment to the Organization", Journal of $320 \quad$ Occupational Psychology, Vol. 63,1-18.

321 2. Angle (1983). Organizational commitment: Individual and organizational influences. 322 Work and Occupations, 123-146 
14 of 16

323

324

325

326
3. Arthur, J. (1994). Effects of human resource systems on manufacturing performance and Turnover. Academy of Management Journal, Vol: 37, 670-687

4. Baron, R. M., \& Kenny, D. A. (1986). The moderator-mediator variable distinction in social psychological research: Conceptual, strategic, and statistical considerations. Journal of Personality and Social Psychology, 51, 1173-1182.

5. Bartlett, C., \& Ghoshal, S. (2013). Building competitive advantage through people. Sloan Mgmt. Rev, Vol: 43(2).

6. Chambers, E., Foulon, M., Handfield-Jones, H., Hankin, S., Michaels III, E., 1998. The war for talent. The McKinsey Quarterly, Vol: 3(1), 44-57.

7. Chen, M. (2014, January). The Effect of Training on Employee Retention. In 2014 International Conference on Global Economy, Commerce and Service Science (GECSS-14). Atlantis Press.

8. Comrey \& Lee (1992). A first course in factor analysis. Hillsdale, NJ: Erlbaum.

9. Davies, R. (2001). How to boost staff retention. in people anagement.Vol:7(8):54-56.

10. Davis (1996). Business Research for Decision Making, Fourth Edition, Belmont, California: Duxbury Press, 86-113,

11. Delaney, J.T. \& Huselid, M.A. (1996). The impact of human resource management practices on perceptions of organizational performance in for - profit and non - profit organizations. Academy of Management Journal, Vol:39, 949-969

12. Fischer, R. (2011). Cross-cultural training effects on cultural essentialism beliefs and cultural intelligence. International Journal of Intercultural Relations, |Vol: 35, 767-775.

13. Fitz enz, J. (1990).Getting and keeping good employees. In personnel.Vol: 67(8): 25-29.

14. Hair, J. F. Jr., Anderson, R., Tatham, R., and Black, W. C. (1998). Multivariate Data Analysis (5th ed.). Upper Saddle River, NJ: Prentice Hall 
15 of 16

349

350

351

352

353

354

355

356

357

358

359

360

361

362

363

364

365

366

367

368

369

370

371

372

373

374

375

376

377

15. Hall, R. (1993). "A framework linking intangible resources and capabilities to sustainable competitive advantage." Strategic management journal,Vol: 14(8):607-618.

16. Hausknecht, J. P., Rodda, J., \& Howard, M. J. (2009). Targeted employee retention: Performance-based and job-related differences in reported reasons for staying. Human Resource Management,Vol: 48(2), 269-88.

17. Highhouse, S, Stierwalt, S.L, Bachiochi, P, Elder, A.E and Fisher, G, (1999), Effects of advertised human resource management practices on attraction of African American applicants”, Personnel Psychology, Summer, Vol:52(2),425(1).

18. Huselid, M. A. (1995). "The impact of human resource management practices on turnover, productivity, and corporate financial performance", Academy of Management Journal, Vol: 38, 635-672.

19. Jamrog, J. J. (2002) The coming decade of the employee. Human Resource Planning, Vol: $25(3), 5-11$.

20. Judd, C. M., \& Kenny, D. A. (1981). Process analysis: Estimating mediation in treatment evaluations. Evaluation Review, 5, 602-619.

21. Koys (2001), The Effects Of Employee Satisfaction, Organizational Citizenship Behavior, And Turnover On Organizational Effectiveness: A Unit-Level, Longitudinal Study, International journal of personnel psychology, vol: 54(1), 101-114.

22. Mercer Report, (2003). Mercer study raises red flags for employer pay and benefits plans (findings of the 2002 people at work survey). In human resource department management report, 8-15.

23. Nelson, K., McCann, J. E., 2010. Designing for knowledge worker retention \& organization performance. Journal of Management and Marketing Research, Vol: $1,1-18$

24. Nunnally (1978). Psychometric Theory, McGraw-Hill Book Company, 190-255.

25. Parker, O \& Wright, L, (2001), "Pay and Employee Commitment: the missing link", Ivey Business Journal, Vol: 65(3), 70. 
16 of 16

378

379

380

381

382

383

384

26. Phillips, J. J. (1997a). Handbook of training evaluation and measurement methods (3rd edition.).Boston: Butterworth-Heinemann.

27. Porter, Steers, R., Mow day, R. \& An Ban lain, P. (1979). Organizational Commitment, Job Satisfaction and Turnover among Psychiatric Technicians. Journal of Applied Psychology. Vol: 59.

28. Rynes and Barber (1990). "Applicant attraction strategies: An organizational perspective", Academy of Management Review, Vol: 15, 286-310

29. Spreitzer (1997) an empirical examination of a comprehensive model of psychological empowerment in the workplace, American Journal of community, 23(5), 601-629.

30. Steers (1977) Antecedents and consequences of organizational commitment. Administrative Science Quarterly, Vol: 22, 46-56

31. Taylor, S. (2002). Occupational Pensions and Employee Retention: Debate and Evidence. Employee Relations, Vol: 22(3), 246-259.

32. Tower Perrin, (2003). Rewards: the not so secret ingredient for managing talent. (Retention). HR focus, Vol: 80 (1):3-10.

33. Watson, Wyatt. (1999). Work USA 2000: Employee commitment and the bottom line. Bethesda, MD: Watson Wyatt, 43-58.

34. Wiens-Tuers, B. \& Hill, E. (2002) Do They Bother? Employer Training of Temporary Workers. Review of Social Economy, Vol: 60 (4), 543-566.

35. Williams and Dreher (1992), “Compensation systems attributes and applicant pool characteristics", Academy of Management Journal, Vol: 4 35. 571-595. 